\title{
THE EFFECTIVENESS OF PLANNED TEACHING PROGRAMME ON SELECTED FIRST AID MEASURES AMONG B.Ed. STUDENTS
}

Mr. Devendra Singh* I Dr. Rajendra Prasad Sharma**

*Principal Sanskar College of Nursing, Jaipur, Rajasthan, India.

**Associate Professor, Mahatma Gandhi Nursing College, Jaipur, Rajasthan, India. DOI: http://doi.org/10.47211/trr.2021.v07i01.004

\section{ABSTRACT}

From the perspective of the $21^{\text {st }}$ century the need for first aid training seems self-evident, but the history of organized first aid span is only 120 years. There is evidence that Native Americans practiced first aid and taught it. Modern first aid evolved from military experience when surgeons taught soldiers how to splint and bandage battle field wound. Training in first aid was begun in United States in 1903 when Clara Borton was the President of the ARC, formed a committee to give instruction of first aid among the nation's industrial workers, where dangerous conditions, accidents and death are too frequent. First aid is the immediate and temporary proper aid provided to a sick or injured person until medical treatment can be provided it generally consist of series of simple life saving medical techniques that a non-doctor or lay person can be trained to perform with minimal equipment. First aid can make the difference between life and death. Children are more active and adventurous and they are more vulnerable to accidents and injuries.

Key Words: Vulnerable, Sickness, First Aid, Injuries.

\section{ABOUT AUTHORS:}

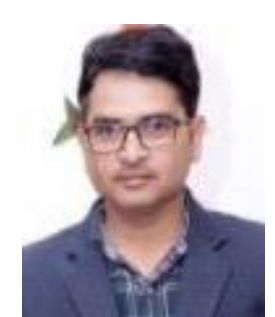

Author Mr. Devendra Singh is working as Principal Sanskar College of Nursing, Jobner Road Fulera Jaipur, Rajasthan, India. He has attended various webinars, seminars and conferences.

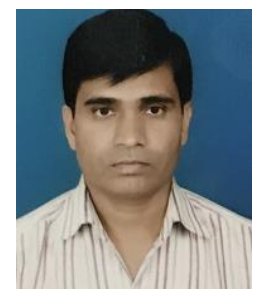

Author Dr. Rajendra Prasad Sharma is working as Associate Professor at Mahatma Gandhi Nursing College Jaipur, Rajasthan, India. He has a Research Guide for PG and Ph.D. Scholar. He has Presented Papers at Various Seminars and Conferences. 


\section{ARTIC LES}

\section{INTRODUCTION}

Accidents are the most common cause of mortality in children and account for considerable childhood mortality. The identification of risk factors for childhood accidents suggests that many are predictable and therefore preventable ${ }^{2}$.

If the child and the future teacher are given teaching, most of the accidents can be prevented. School children form a significant and important segment of the population. They need maximum attention in terms of their education, health, social and emotional development. In India, school health services exist primarily to preserve and promote the health of the children. The cordial relationship between class teacher and students provide a good platform for school health services. W.H.O also emphasized the need to prepare the teachers to deal with sensitive issue and refer students with defects and deviations from normal health ${ }^{3}$.

The goal of first aid is to save life to prevent an injury or illness from getting worst and help speed recovery ${ }^{4}$. Learning first aid is a civic responsibility of each citizen. Even though methods of first aid have been practiced perhaps ever since a man desired to help another man in sickness or after injury.

\section{OBJECTIVES OF THE STUDY}

1. To assess the level of knowledge of B.Ed. students in selected first aid measures.

2. To develop and validate a planned teaching programme on selected first aid measures.

3. To find the effectiveness of planned teaching programme on B.Ed. students in terms of gain in knowledge scores regarding selected first aid measures.

4. To determine the association between knowledge on selected first aid measures and the selected demographic variables such as age, marital status and source of information on first aid.

\section{HYPOTHESIS}

Hypothesis is the researcher's prediction of the relationship the researchers expect to find. ${ }^{14}$

The entire hypothesis will be tested at $5 \%$ level of significance.

$\mathrm{H}_{1}$ :- The mean post test knowledge score of B.Ed students who have undergone P.T.P will be significantly higher than their mean pre-test knowledge score.

\section{$\mathrm{H}_{2}$ :- There will be a significant association between the pre-test knowledge score and selected variables.}

\section{METHOD AND MATERIAL}

Sample

A sample is a portion of the population that has been selected to represent the population of interest 15 .

The sample for the present study comprised of 60 B.Ed. students.

\section{Sampling Techniques}

Sampling techniques is the procedure which the researcher adopts in selecting the sample for the study 14.

For the present study simple random sampling technique was used to select the sample.

RESULTS

Table- 1 Distribution of pre-test and post-test knowledge scores of the sample on selected first aid Measures $n=60$

\begin{tabular}{|l|l|l|l|l|}
\hline Score & Pre-test & Post-test & \\
\hline \multirow{2}{*}{ Poor(0-11) } & Frequency & Percentage & Frequency & Percentage \\
\cline { 2 - 5 } & 4 & 6.66 & - & - \\
\hline Average(11-22) & 56 & 93.33 & - & - \\
\hline Good(22-32) & - & - & 60 & 100 \\
\hline
\end{tabular}

The samples score ranged from 0-32. Where the maximum possible score is 32 . Further the data showed in the pre-test that majority of the samples 56(93.33\%) scored between the range of (11-22) average and 4 (6.66\%) of the subjects scored between the range of (0-11) poor. Further the data showed in the post-test that all sample scored between the ranges of (22-32) good. 


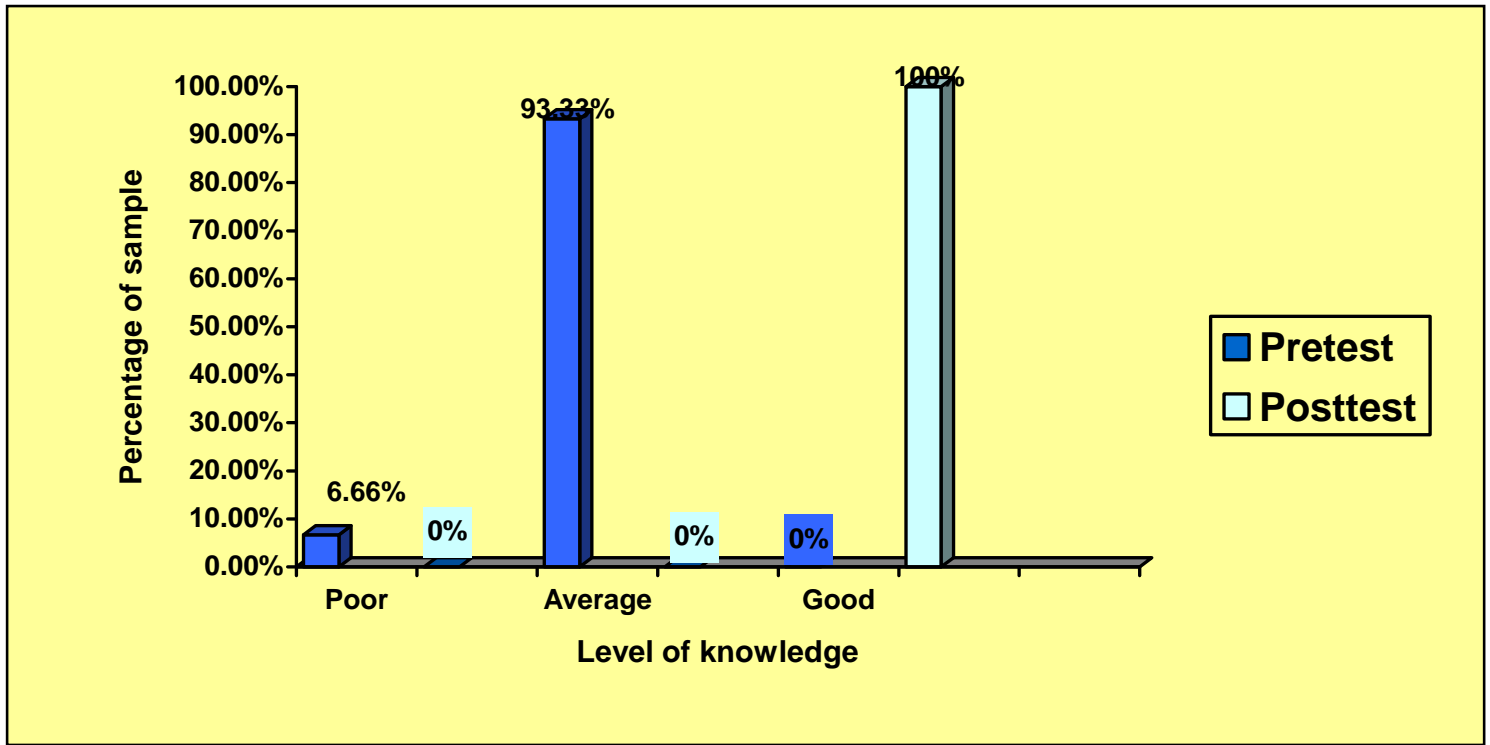

Figure .1 Diagram representing the pre-test and post-test knowledge scores of sample.

Table 2 Mean; Mean difference, Standard error of difference and ' $t$ ' value of pre-test and post-test scores.

\begin{tabular}{|l|l|l|l|l|l|l|}
\hline & Mean & $\begin{array}{l}\text { Mean } \\
\text { difference }\end{array}$ & Standard error & $\begin{array}{l}\text { 't' } \\
\text { value }\end{array}$ & d.f. & L.O.S. \\
\hline Pre-test & 14.233 & 12.4167 & .3488 & 35.602 & 59 & $\begin{array}{l}\text { p }<0.05 \\
\text { H.S. }\end{array}$ \\
\cline { 1 - 6 } & & & & & & \\
\hline
\end{tabular}

" $\mathrm{t}$ " table value for $59=2.0008 \quad \mathrm{p}<0.05 \mathrm{H} . \mathrm{S} \quad$ H.S. - highly significant

The data in table show that the mean post test knowledge scores of subjects were significantly higher than their mean pre-test knowledge scores. ' $t$ ' $=35.602$. Hence the null hypothesis $H_{0}$ was rejected and research hypothesis was accepted indicating that the gain in knowledge by planned teaching programme.

Further area wise analysis was done to find the significant difference between pre-test and post-test scores, a paired ' $\mathrm{t}$ ' test was computed.

Table-3 Association between the level of knowledge and age, marital status and source of information on first aid.

\begin{tabular}{|c|c|c|c|c|c|c|c|}
\hline \multirow{2}{*}{ S.No. } & \multirow{2}{*}{$\begin{array}{l}\text { Demographic } \\
\text { variables }\end{array}$} & \multicolumn{3}{|c|}{ Level of knowledge } & \multirow{2}{*}{$\begin{array}{l}\text { Chi- } \\
\text { square } \\
\text { value }\end{array}$} & \multirow{2}{*}{$\begin{array}{l}\text { Degree of } \\
\text { freedom }\end{array}$} & \multirow{2}{*}{$\begin{array}{c}\text { Level of } \\
\text { significance }\end{array}$} \\
\hline & & Poor & Average & Good & & & \\
\hline 1 & $\begin{array}{l}\text { Age in years } \\
21-23 \\
24-26 \\
27-29 \\
30-32 \\
\end{array}$ & $\begin{array}{l}3 \\
1 \\
-- \\
--\end{array}$ & $\begin{array}{l}45 \\
9 \\
-- \\
2 \\
\end{array}$ & $\begin{array}{l}-- \\
-- \\
-- \\
--\end{array}$ & 0.1506 & 1 & $\begin{array}{l}p>0.05 \\
\text { N.S. }\end{array}$ \\
\hline 2 & $\begin{array}{l}\text { Marital status } \\
\text { Married } \\
\text { Unmarried }\end{array}$ & -- & $\begin{array}{l}4 \\
56\end{array}$ & $\begin{array}{l}-- \\
-\end{array}$ & 0.2343 & 1 & $\begin{array}{l}p>0.05 \\
\text { N.S }\end{array}$ \\
\hline 3 & $\begin{array}{ll}\begin{array}{l}\text { Source } \\
\text { information }\end{array} & \text { of } \\
\text { first aid } & \\
\text { News paper } & \\
\text { Television } & \\
\text { Friends } & \\
\text { Any others } & \end{array}$ & $\begin{array}{l}1 \\
2 \\
1 \\
---\end{array}$ & $\begin{array}{l}10 \\
10 \\
4 \\
32\end{array}$ & $\begin{array}{l}-- \\
-- \\
--\end{array}$ & 1.0588 & 1 & $\begin{array}{l}p>0.05 \\
\text { N.S }\end{array}$ \\
\hline
\end{tabular}

$\chi^{2}$ table value at $5 \%$ level of $S 3.841$

N.S.- Not significant 


\section{ARTICLES}

Table-3 shows that there was no significant association between the knowledge and selected demographic variables.

a) From the above mentioned data there was no significant association between the- level of knowledge and age, ? $^{2}$ calculated value is $(0.1506 \mathrm{p}<0.05)$ at 0.05 level of significance. Hence the null hypothesis is accepted and research hypothesis is rejected.

b) There was no significant association between level of knowledge and marital status, ${ }^{2}{ }^{\text {calculated }}$ value is $(0.2343 \mathrm{p}<0.05)$ at 0.05 level of significance. Hence the null hypothesis is accepted and research hypothesis is rejected.

c) There was no significant association between level of knowledge and source of information on first aid $~^{2}$ calculated value is $(1.0588 \mathrm{p}<0.05)$ at 0.05 level of significance. Hence the null hypothesis accepted is and research hypothesis is rejected

\section{CONCLUSION}

It is based on the findings of the study:-

- Majority of the subjects 48 (80\%) were in the age group of 21-23 years, and all were female, and majority of the subjects 56 (93.33\%) were single/ unmarried.

- The data showed that maximum 56 (93.33\%) subjects had average knowledge.

- The mean pre-test knowledge score was 14.233 whereas the maximum possible score was 32 .

- Highest post test mean percentage score 92.77 was in the area of insertion of foreign body.

- The maximum modified gain was in the area of insertion of foreign body (.861)

- The chi-square test was computed in order to determine the association between the level of knowledge and the selected variables age, sex, marital status and source of information on first aid indicated that there was no association between level of knowledge and the selected variables.

\section{REFERENCES}

1. Denis Kendrick British Journal of General practice Aug- 1994.

2. Dr. Sarkar Amitabha, Dr. Malik Sarmila Dr. Bisoi, Sukamal Prof. Biswas Ranadeb. Evaluation of a training programme for primary school teachers on first aid and referral of the sick children. Health promotion and Education in South East Asia; Apr 2007; 39-45. www.veterinarypartner.com/ content. Plx (20/12/2009)

3. Guide line for first aid Sponsored by American Red cross and American Heart Association.

4. Polit, D. F, Hungler Bernadette P. Nursing research. Principles and methods, 6 th edition. Philadeplia: Williams and Wilkins; 2004.

5. Talbot. LA Principal and Practice of Nursing Research, St. Louis Missouri. Mosby Year book. 1995. 